\title{
UNDERWRITING PADA ASURANSI JIWA SYARIAH DALAM PERSPEKTIF MAQASHID SYARIAH (STUDI KASUS PADA ASURANSI TAKAFUL KELUARGA CABANG BENGKULU)
}

\author{
Muhammad Ilham, Asasriwarni, Fitri Yeni Dalil \\ Kantor Kementerin Agama Bengkulu Utara, \\ Jl. Prof. M. Yamin SH, No. 40 Kelurahan Gunung Alam, Kec. Arga Makmur, Bengkulu Utara \\ IAIN Batusangkar \\ e-mail : muhammadilhamm95@gmail.com
}

\begin{abstract}
The problems discussed in this paper are underwriting in sharia life insurance case studies on the Takaful insurance Bengkulu family branch. The aim is to find out the implementation of underwriting, factors that are considered underwriters, and how Maqasid sharia views on underwriting implementation at the Bengkulu Branch Family Takaful Insurance. The method used is descriptive qualitative analysis. In this case the writer describes the data the author gets from interviews and documentation from primary data sources and secondary data, while the data analysis techniques used are inductive analysis techniques by taking keywords from the results of interviews, then making narratives with easy-to-understand relationship patterns, then steps finally verify and draw conclusions from the results of the study. Based on the research that the author did in the Bengkulu Branch Family Takaful Insurance, it can be concluded that underwriting starts from field underwriting, verification of file and application data, collecting additional information, assessing risk, and underwriting decisions. Types of decisions, namely; insurance is accepted standard, insurance is accepted substandard, insurance is postponed, and insurance is refused. Then the factors that are considered by the underwriter in selecting risk include medical and non-medical factors. Maqasid sharia's view of underwriting is the first protection of the soul (Hifz al-Nafs). The legal objectives of underwriting are so that the risks are relatively homogeneous from certain groups of participants in order to provide a risk sharing scheme that is propo"rtional, fair and affordable to fellow policyholders against the risks that will be experienced. Second protection of property (Hifz al-Maal) The legal objective of underwriting is that the relatively large risks are offset by large savings and savings funds, in order to provide a risk sharing scheme that is proportional, fair and affordable to fellow policyholders and also provide space for companies to manage the premium funds on productive roads which are certainly in accordance with Islamic principles
\end{abstract}

Keyword: underwriting, Sharia life insurance, Maqashid syari'ah

\section{PENDAHULUAN}

Manusia dengan segala macam

cara berusaha untuk dapat mencari jalan keluar jika terjadi masalah dalam kegiatan ekonomi. Sebagai makhluk yang selalu berkembang manusia pasti mengembangkan upaya-upaya memperkecil terjadinya resiko, 
manusia tetap tidak bisa meramalkan kapan dan pada siapa resiko itu akan terjadi. Namun sebagai umat Islam, tentu kita harus berpegang pada hukum agama kita.

Salah satu persoalan didalam dunia Islam masa kini dalam bidang ekonomi adalah Asuransi. Asuransi dalam ensiklopedi hukum Islam disebutkan bahwa asuransi (at $t a^{\prime}$ min) adalah "transaksi perjanjian antara dua pihak, pihak yang satu berkewajiban membayar iuran dan pihak yang lain berkewajiban memberikan jaminan sepenuhnya kepada pembayar iuran jika terjadi sesuatu yang menimpa pihak pertama sesuai perjanjian yang dibuat (Rezky Kun A, 2015 : 11).

Prinsip utama dari asuransi syariah adalah ta'awanu 'ala birri wa altaqwa. Prinsip ini menjadikan para anggota asuransi sebagai keluarga besar yang satu dan yang lainnya saling menjamin dan menanggung resiko. Dalam asuransi mengandung semangat gotong royong, kebersamaan, dan saling membantu antar sesama, serta belum ditemukannya gharar, maysir, ataupun dzalim didalamnya, inilah yang menjadi dasar mengapa Islam perlu mengembangkan keberadaan asuransi menurut hukum Islam. Sebagaimana firman Allah SWT dalam QS ALMaidah ayat 2

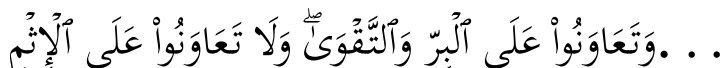

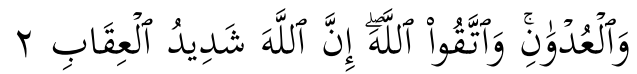

Artinya : “. . . Dan tolong-menolonglah kamu dalam (mengerjakan) kebajikan dan takwa, dan jangan tolong-menolong dalam berbuat dosa dan pelanggaran. Dan bertakwalah kamu kepada Allah, sesungguhnya Allah amat berat siksaNya."

Pada dasarnya asuransi syari'ah terbagi atas 2 bagian besar: yaitu pertama ialah asuransi yang bersifat umum (general insurance) yang meliputi semua harta benda untuk menjadi objek yang akan ditanggung, kemudian yang kedua ialah asuransi jiwa (life insurnace) yang meliputi jiwa raganya seseorang manusia untuk menjadi objek yang akan di tanggung.

Menurut Heri Sadarsono (2004 : 235) Asuransi jiwa syari'ah yaitu jenis asuransi syari'ah yang khusus mengelola resiko berkaitan dengan hidup atau meninggalnya seseorang. Tidak terbatas pada pemberian santunan apabila ada peserta yang mengalami musibah dan perencanaan keuangan peserta pada masa mendatang.

Dalam kegiatan bisnis asuransi khususnya asuransi jiwa segala sesuatu diarahkan untuk memproteksi keadaan dimasa mendatang yang 
belum pasti terjadi atas sebuah resiko yang berkaitan dengan nilai aktivitas ekonomi seseorang. Menghadapi sesuatu yang akan datang tidak mungkin dapat dipungkiri oleh manusia, walaupun dalam wujudnya keadaan yang tidak akan terjadi dimasa mendatang itu belum jelas realitanya. Ini dikarenakan kenyataan dari kehidupan manusia berjalan secara linier yang terikat oleh masa lalu, masa sekarang, dan masa yang akan datang. Seseorang tidak akan dapat memastikan apakah dia masih hidup atau dalam keadaan sehat dimasa yang akan datang atau juga apakah keadaan harta seseorang akan tetap terhindar dari musibah atau bencana.

Dalam operasional asuransi jiwa syariah yang sebenarnya terjadi ialah saling bertanggung jawab, melindungi dan untuk membantu diantara peserta sendiri. Perusahaan asuransi diberikan kepercayaan dari para peserta asuransi untukmengelola premi, mengembangkan dengan jalan yang halal, memberikan bantuan kepada yang mengalami musibah sesuai isi perjanjian. Adapun proses yang harus dilewati seputar mekanisme kerja asuransi syariah dapat diuraikan salah satunya ialah underwriting (Permata Hastuti, 2016 : 18).
Underwriting menurut pengertian asuransi jiwa ialah proses penaksiran dan klasifikasi mortalitas dan morbiditas calon tertanggung untuk menetapkan pengajuan asuransi calon peserta akan diterima atau ditolak. Mortalitas merupakan jumlah kejadian meninggal diantara sekelompok orang tertentu, sedangkan morbiditas merupakan jumlah kejadian penyakit diantara sekelompok orang tertentu. Pada asuransi syari'ah prinsip underwriting sama dengan asuransi konvensional. Namun dalam asuransi syari'ah, untuk menyeleksi resiko secara implisit tergabung dua elemen penting yaitu, seleksi dan pengklasifikasian. Penekanan utama pada underwriting syari'ah bersifat wasathon (tengah-tengah) yaitu penekanan pada rasa keadilan bagi nasabah dan perusahaan (Abdullah, 2006 : 57).

Menurut peraturan yang dilekuarkan oleh Otoritas Jasa Keuangan mengenai Penyelenggaraan Usaha Perusahaan Asuransi, Perusahaan Asuransi Syariah, Perusahaan Reasuransi, Dan Perusahaan Reasuransi Syariah menyatakan bahwa Perusahaan atau Unit Syariah wajib memiliki pedoman underwriting untuk produk yang dipasarkan, yang mencerminkan bahwa pelaksanaan proses seleksi 
risiko dilakukan secara hati-hati dan sesuai dengan praktik perasuransian yang berlaku umum (pasal 34 POJK No 69/POJK.05/2016). Artinya mengenai pedoman underwriting OJK mengizinkan untuk di kendalikan penuh oleh perusahaan asuransi masing-masing.

Dalam melakukan proses underwriting terdapat 3 konsep penting bagi perusahaan. Pertama, kemungkinan akan menderita kerugian, kondisi yang seperti ini diramalkan berdasarkan pada apa yang telah terjadi dimasa lalu. Kedua, tingkat resiko, yaitu ketidak ada kepastian akan kerugian pada masa yang akan datang. Ketiga, hukum bilangan dimana makin banyak objek yang mempunyai resiko yang sama atau hampir sama, akan makin bertambah baik bagi perusahaan karena penyebaran resiko akan lebih luas dan kemungkinan menderita kerugian dapat secara sistematis diramalkan.

Banyak pertimbangan yang harus dilakukan oleh underwriter demi kemaslahatan para pemegang polis dan kemaslahatan bagi kelancaran keuangan perusahaan asuransi. Untuk itu dalam seleksi resiko tersebut underwriter perlu hati-hati dalam menjaring para calon penegang polis tetapi tidak mengenyampingkan prinsip tolong-menolong dalam asuransi. Salah satu yang dapat dilakukan oleh underwriter ialah dengan pendekatan maqashid syari'ah.

Seiring berkembangnya zaman, ilmu maqashid syari'ah kini telah banyak digunakan sebagai acuan dalam sebuah permasalahan atau isuisu masa kini. Para ulama ushul fikih juga telah bersepakat bahwa pengetahuan maqashid syari'ah menjadi hal utama dalam berijtihad untuk menjawab berbagai problematika kehidupan ekonomi dan keuangan yang terus berkembang seiring berkembangnya zaman.

Maqashid syariah tidak saja menjadi faktor yang paling menentukan dalam melahirkan produk-produk ekonomi syari'ah. Namun juga sebagai alat sosial kontrol dan rekayasa socio-economy untuk mewujudkan kemaslahatan manusia, dan lebih dari itu, maqashid syari'ah dapat memberikan dimensi filosofis dan rasional terhadap produk-produk hukum ekonomi syariecah yang dilahirkan dalam aktivitas ijtihad ekonomi syari'ah kontemporer.

Berdasarkan wawancara awal penulis pada Asuransi Takaful Keluarga cabang Bengkulu, bahwa ada beberapa prosedur yang dilewati sebelum menjadi tertanggung untuk kemudian memberikan 
pertanggungan asuransi sesuai Apabila kondisicalon peserta dibawah dengan yang diinginkan. Prosedur ketentuan polis, maka ada 2 pilihan. tersebut dimulai sewaktu calon Yang pertama calon peserta ditolak pemegang polis mengisi surat kemudian pilihan kedua jumlah premi permohonan untuk menjadi pihak ditambahkan, sehingga jumlah premi yang ditanggung. Dalam prosedur ini pun berbeda dengan peserta lainnya. calon pemegang polis mengisi data (Arif, wawancara pra-riset, 05 pribadi, kemudian para agen September 2018). memprediksi kelas resiko yang akan Inilah yang mendasari peneliti diterima. Kemudian tahap berikutnya tertarik untuk melakukan penelitian verivikasi berkas dan data aplikasi. terkait dengan Asuransi Jiwa Syari'ah Setelah itu aplikasi dikirim ke kantor yang secara khusus ingin dilakukan pusat, aplikasi permohonan di periksa, pada perusahaan Asuransi Takaful diverivikasi, dan di seleksi. Sebelum di Keluarga cabang Bengkulu, karena taksir oleh underwriter kantor pusat. perusahaan tersebut selektif dalam Setelah itu apabila dinilai kurang maka melakukan underwriting dan dikumpulkanlah informasi tambahan perusahan tersebut secara mengenai kondisi calon pemegang kelembagaan khusus menangani polis. Informasi tambahan bisa dengan operasional secara sistem syari'ah laporan pemeriksaan kesehatan, tidak bercampur dengan sistem keterangan dokter pribadi, dan konvensional.

keterangan agen terhadap kondisi calon pemegang polis. Kemudian dilanjutkan dengan penggolongan resiko, penggolongan resiko dilakukan untuk memproses klasifikasi calon peserta yang memiliki tingkat resiko yang sama. Setelah itu, barulah keputusan dari underwriting. Pada seleksi resiko terdapat dua kemungkinan yaitu memenuhi ketentuan polis atau tidak memenuhi ketentuan polis. Apabila kondisi calon peserta tidak dibawah ketentuan polis maka diberlakukan premi standar.

Penulis juga mewawancarai salah seorang calon pemegang polis yang awalnya ingin bergabung dengan asuransi takaful keluarga cabang Bengkulu. Beliau pensiunan BUMN yang umurnya kurang lebih 57 tahun. Karena faktor umur tersebut banyak syarat yang beliau terima untuk bergabung dalam asuransi tersebut, singkat cerita akhirnya calon pemegang polis tersebut membatalkan untuk bergabung pada asuransi Takaful Keluarga cabang Bengkulu dan pindah ke perusahaan asuransi 
lain karena ketatnya proses underwriting pada asuransi takaful kelaurga cabang Bengkulu tersebut (Asep, wawancara pra-riset, 06 september 2018).

Mengingat resiko yang ada pada calon peserta yang menjadi tolak ukur diterima atau tidak nya suatu permohonan asuransi, maka di sini proses underwriting sangatlah penting. Berdasarkan penggolongan dan penaksiran tingkat resiko tersebut, di dalam underwriting perusahan berhak memutuskan menerima atau tidak resiko-resiko tersebut. Oleh karena itu, perusahaan harus menganalisis resikoresiko apa saja yang ada pada calon tertanggung sesuai prosedur yang berlaku. Namun dalam proses underwriting yang terjadi terdapat penyimpangan atas ketentuan yang berlaku terhadap prinsip asuransi jiwa syariah yaitu dalam penyeleksian resiko pihak asuransi jiwa syariah ini tidak mengutamakan prinsip tolong menolong dan saling melindungi dimana jika perusahaan menilai resiko tersebut terlalu besar maka permohonan asuransi nya tidak bisa di cover. Perusahaan Asuransi secara langsung menolak calon tertanggung atau nasabah yang tidak lolos seleksi resiko dikarenakan calon tertanggung atau nasabah ini kurang mampu dan dianggap tidak cocok untuk mengambil polis asuransi karena pihak perusahaan mempunyai kriteria tertentu untuk menerima nasabah mulai dari segi umur, pekerjaan bahkan riwayat keluarga. Tolong menolong yang terjadi di perusahaan asuransi jiwa syari'ah yaitu tolong menolong yang ada timbal balik nya dimana peserta membayarkan premi kepada pihak perusahan kemudian pihak perusahaan akan memberikan jaminan jika terjadi musibah nantinya dengan mengajukan klaim. Sedangkan tolong menolong dalam Islam itu tanpa terkecuali dalam berbuat kebajikan, kita di anjurkan untuk menolong terhadap orang yang membutuhkan.

Berdasarkan latar belakang yang telah penulis uraikan diatas, maka penulis tertarik melakukan penelitian yang berjudul Underwriting Pada Asuransi Jiwa Syariah dalam Perspektif Maqashid Syariah (Studi kasus pada Asuransi Takaful Keluarga Cabang Bengkulu)" . Sedangkan yang menjadi rumusan dalam masalah ini yaitu:

1. Bagaimana pelaksanaan underwriting pada perusahaan Asuransi Takaful Keluarga Cabang Bengkulu?

2. Apa saja faktor yang menjadi pertimbangan underwriter dalam 
menyeleksi resiko pada Asuransi Takaful Keluarga Cabang Bengkulu.

3. Bagaimana pandangan maqashid syariah terhadap pelaksanaan underwriting pada perusahaan asuransi Takaful Keluarga Cabang Bengkulu?

\section{KAJIAN PUSTAKA}

\section{Asuransi Jiwa Syari'ah}

Menurut Gamela Dewi (2004 : 139) asuransi jiwa syari'ah adalah bentuk asuransi syari'ah yang memberikan perlindungan dalam menghadapi musibah kematian dan kecelakaan atas diri peserta asuransi.

Asuransi jiwa adalah suatu jasa yang diberikan oleh perusahaan dalam penanggulangan resiko yang dikaitkan dengan jiwa atau meninggalnya seseorang yang diasuransikan. Asuransi jiwa merupakan suatu bentuk kerja sama antara orang-orang yang ingin menghindarkan atau minimal mengurangi resiko yang diakibatkan oleh resiko kematian, resiko hari tua, dan resiko kecelakaan. Usaha perasuransian adalah perusahaan asuransi jiwa yang telah memperoleh izin usaha dari Menteri Keuangan yang dapat melakukan kegiatan pertanggungan jiwa.

Adapun yang menjadi landasan hukum asuransi jiwa sayari'ah terdapat dalam Surah Ali Imran [3] : 145 dan 185

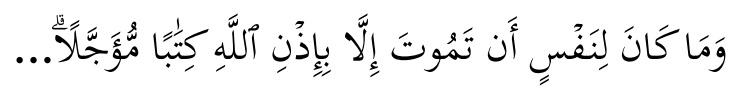

Artinya: "Sesuatu yang bernyawa tidak akan mati melainkan dengan izin Allah, sebagai ketetapan yang telah ditentukan waktunya..."

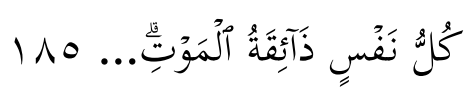

" Tiap-tiap yang berjiwa akan merasakan mati..."

Kedua ayat ini menjelaskan bahwa kematian (ajal) adalah sesuatu yang bersifat pasti adanya dan akan menimpa bagi sesuatu yang memiliki nyawa, termasuk di dalamnya manusia

Adapun bentuk - bentuk dari asuransi jiwa syari'ah antara lain (Warkum Sumitro, 1996 : 171-172) :

a. Asuransi Jiwa Berencana (Takaful Berencana)

b. Asuransi Jiwa Pembiayaan (Takaful Pembiayaan)

c. Asuransi Jiwa Pendidikan (Takaful Pendidikan)

d. Asuransi jiwa Dana Haji (Takaful Dana Haji)

e. Asurnasi Jiwa Berjangka (Takaful Berjangka)

f. Asuransi Jiwa Kesehatan (Takaful Kesehatan)

g. Asuransi jiwa perjalanan haji dan umrah (Takaful perjalanan haji dan umrah) 
h. Asuransi jiwa wisata dan perjalanan (Takaful wisata dan perjalanan).

Underwriting Dalam Asuranasi Jiwa Syariah

Underwriting menurut asuransi jiwa adalah proses penaksiran mortalitas (tingkat kematian) atau mordibitas (tingkat kesehatan) calon tertanggung untuk menetapkan apakah akan menerima atau menolak calon peserta dan menetapkan klasifikasi peserta (Abdullah Amrin, 2006 : 103).

Konsep dasar underwriting syariah adalah memberikan skema pembagian resiko yang proposional dan adil di antara peserta asuransi yang relative homogen. Melalui asuransi syariah diharapkan para peserta saling tolong menolong satu sama lain dengan adanya perlindungan yang sifatnya mutual maka semua peserta akan dan menikmati perlindungan yang mereka butuhkan.

Seorang underwriter adalah bagian penting dari perusahaan asuransi. Untuk itu tugas dan fungsi underwriter harus dijalankan dengan prinsip keadilan, baik untuk peserta atau perusahaan asuransi.

Tujuan utama underwriting adalah melindungi perusahaan terhadap seleksi kerugian. Namun, proses underwriting perusahaan asuransi tetap berfokus pada pemberian persetujuan dan penerbitan pertanggungan.

Jenis-Jenis resiko yang mempengaruhi underwriting adalah sebagi berikut: (Abdullah Amrin, 2006 :105).

a) Increasing risk (risiko menarik) Ada beberapa penyakit tertentu,misalnya besarnya risiko akan bertambah berat sesuai dengan kenaikan umur calon tertanggung

b) Risiko yang tinggi dialami pada tahun-tahun pertama polis. Makin lama polis berjalan, risiko semakin menurun

c) Constant extra risk (risiko ekstra yang menetap), pada jenis ini,risiko tambahan berada pada tingkat yang tetap selama masa pertanggungan.

Proses underwriting yang efektif underwriter harus mengumpulkan sebanyak mungkin informasi tentang pokok- pokok asuransi dalam batasbatas waktu dan biaya memperoleh data tambahan. Dimulai dari proses Surat permintaan, Analisis resiko, dan Penerbitan Polis.

Underwriting asuransi jiwa syariah mempunyai tujuan yang sangat berbeda. Konsep dasarnya memberi skema pembagian resiko yang proposional dan adil diantara para peserta yang secara relatif homogen. Melalui asuransi jiwa 96 | Jurnal Tamwil, Vol. VI, No. 2, Juli-Desember 2020 
syariah diharapkan para peserta tolong-menolong satu sama lain disertai dengan adanya perlindungan yang sifatnya matual, maka semua peserta akan merasa aman dan menikmati perlindungan yang mereka butuhkan.

Persamaan underwriting syariah yang mewakili sebuah model wakalah:

Rasio Ongkos Murni

+ Rasio Biaya Akuisisi

Operator

+ Rasio Biaya Wakalah

$$
=100 \%
$$

Dengan menggunakan model underwriting asuransi jiwa syariah dan persamaannya (terutama model wakalah) kita dapat melihat dengan jelas bahwa peserta sebenarnya tidak harus dipilih oleh operator. Sekumpulan peserta yang sulit memperoleh perlindungan yang wajar dari asuransi konvensional dapat bekerjasama satu sama lain untuk memberi perlindungan dengan bantuan operator asuransi jiwa syariah. Pada saat yang sama operator asuransi jiwa syariah tidak terekspos pada kerugian underwrting (Iqbal, 2005 :35).

Untuk melaksanakan konsep underwrting asuransi jiwa syariah yang baik, tantangan bagi underwriter asuransi adalah untuk menemukan jawaban-jawaban dari persoalan di bawah ini (Iqbal, 2005 : 35).
Ada beberapa faktor yang menjadi tolak ukur dalam proses underwriting, secara garis besar ada tiga factor utama yang menjadi factor underwriting, antara lain faktor Umur, Faktor Jenis Kelamin, dan Faktor Medis. Yang menjadi ukuran dalam faktor medis antara lain: Kondisi fisik, Sejarah Personal, sejarah keluarga, dan pekerjaan,

\section{Maqashid Syariah}

Kata maqashid (Amir Syarifuddin, 2008: 231) adalah jamak dari kata maqshad yang artinya adalah maksud dan tujuan. Adapun maqashid syari'ah secara isthilah ada beberapa definisi yang dikemukakan oleh ulama ushul. Di antaranya pengertian yang dikemukakan oleh Syatibi, (t.th : 21):

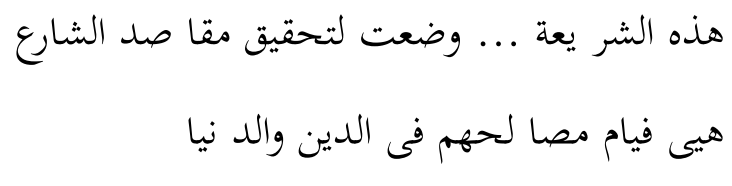

"Inilah syari'at ...ketetapan untuk mewujudkan maqashid syariah bertujuan untuk menegakkan kemaslahatan manusia di dunia dan di akhirat.

Adapun tujuan dari maqashid syari'ah sebagaimana yang diungkapkan oleh Syathibi, (t.th: 4) :

$$
\begin{aligned}
& \text { أن وضع الشارع إنما لمصلح العباد فى }
\end{aligned}
$$

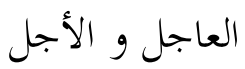

“Sesungguhnya syara' pembuatan hukum yaitu Allah menetapkan hukum adalah untuk kemaslahatan manusia untuk 
kehidupan sekarang (dunia) dan masa yang akan datang (akhirat) swecara bersamaan antara keduanya.

Menurut pandangan Syathibi, tidak satupun hukum Allah yang tidak mempunyai tujuan sama dengan Takhlif ma la Yuthaq (membebankan sesuatu yang tidak dapat dilaksanakan).

Adapun dari segi yang menjadi sasaran atau ruang lingkup yang di pelihara dalam penetapan hukum itu, maqashid syariah (mashlahah) yang ditetapkan oleh nash-nash hukum mengacu kepada lima hal, yaitu:

1) Menjamin keterpeliharaan Agama<smiles>[14CH3][14CH2][14CH3]</smiles>

2) Menjamin keterpeliharaan Jiwa<smiles>[13CH][13CH][13CH3]</smiles>

3) Menjamin keterpeliharaan Akal<smiles>[14CH3][14CH3]</smiles>

4) Menjamin keterpeliharaan

Keturunan(حفظ النسل)

5) Menjamin keterpeliharaan Harta

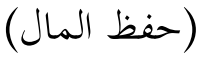

Hukum Islam semata-mata dimaksudkan untuk kemaslahatan manusia di dunia sekaligus di akhirat. Lebih lanjut, ditegaskan bahwa Allah menciptakan hukum untuk mewujudkan dan melindungi maslahah dharuriyah, hajiyah, dan tahsiniyah (Hasby, 1980 : 99).
Mengetahui maksud dari maqashid syariah bukanlah kapasitas dari seorang hamba, hanya Allah swt yang mengetahui maksud yang ada dalam maqasid syariah. Akan tetapi, manusia hanyalah bisa mengira berdasarkan petujuk yang ada, yang hasilnya tentu tidak meyakinkan atau zhanni. Ada beberapa petunjuk yang dapat mengira hal itu, diantaranya (Amir Syarifuddin, 2008 :248):

1) Penjelasan yang diberikan oleh Nabi, baik secara langsung maupun tidak langsung. Untuk itu seluruh hadis Nabi yang berkenaan dengan ayat Al-Quran, harus ditelusuri untuk menemukan kalau ada penjelasan Nabi tentang maksud Allah dalam ayat itu.

2) Melalui asbabun nuzul, itu ditemukan dalam uraian mufasir yang merujuk kepada kejadian yang berlaku pada waktu turunnya suatu ayat.

3) Melalui penjelsan ulama mufasir atau mujtahid atas pemahaman terhadap firman Allah yang berkaitan dengan hukum.

4) Melalui kaidah kebahasaan yang menjelaskan tanda-tanda atau indikasi yang menjelaskan sebab dan akibat seperti yang dipahami dari tanda untuk ta'lil. 


\section{METODE PENELITIAN}

Jenis penelitian yang penulis gunakan adalah penelitian kualitatif dengan pendekatan penelitian lapangan (field research). Penelitian ini dilakukan dengan cara mengkaji praktek underwriting pada Asuransi Takaful Keluarga Cabang Bengkulu, setelah itu akan menganalisis pandangan maqasid syariah mengenai pelaksanaan underwriting tersebut dari literatur-literatur lain yang dapat membantu penelitian ini sehingga akan mendapatkan data yang tepat dan jelas untuk menulis karya ilmiah ini

Penelitian dilakukan di perusahaan Asuransi Takaful Keluarga Cabang Bengkulu provinsi Bengkulu, Indoneisa. Serta waktu penelitian dilakukan dari mulai dari Mei 2018 sampai Februari 2019.

Dalam penelitian kualitatif instrument utamanya ialah peneliti itu sendiri, penelitian ini adalah peneliti sendiri, dan sebagai instrumen pendukung peneliti menggunakan alat bantu recorder dan kamera untuk mengetahui praktik underwriting pada Asuransi Takaful Keluarga Cabang Bengkulu.

Pada penelitian ini sumber data meliputi: Data primer: Pimpinan cabang, pihak undewriter, staf pada Asuransi Takaful Keluarga cabang Bengkulu. Data sekunder : calon pemegang polis, pemegang polis Asuransi Takaful Keluraga Cabang Bengkulu, pihak asuransi jiwa syariah yang menjadi kompotitor Asuransi Takaful Keluraga Cabang Bengkulu, buku fiqih muamalah, fiqih kontenporer, Kompilasi Hukum Ekonomi Syari'ah, UU tentang perasuransian, POJK tentang asuransi, Kamus.

Teknik yang digunakan peneliti dalam pengumpulan data ialah pertama teknik wawancara yaitu dengan Pimpinan, Pihak underwriter, staf, calon pemegang polis dan pemegang polis pada Asuransi Takaful Keluarga Cabang Bengkulu, lalu penulis mewawancarai dengan sistem wawancara semi terstruktur untuk menemukan apa yang akan dicari penulis, kemudian yang kedua teknik dokumentatif, yaitu dengan mengumpulkan data primer mulai dari dokumen-dokumen pendukung dalam proses underwriting, keterangan pemegang polis mengenai proses underwriting dan gambar yang dapat mendukung dalam penelitian ini serta kitab kitab atau buku-buku yang secara langsung berbicara tentang permasalahan yang sedang diteliti dan juga dari data-data sekunder yang secara tidak langsung membicarakannya namun relevan untuk dikutip sebagai pembanding dan diakhir pembahasan penulis akan 
memberikan kesimpulan terkait pembahasan masalah.

Penulis melakukan analisis dengan model Miles dan Huberman, yaitu pada awalnya penulis melakukan Reduksi data dengan cara merangkum dan mengambil hal-hal yang pokok yang diperlukan dalam penelitian penulis, kemudian data tersebut penulis sajikan narasi dengan pola hubungan yang mudah dipahami agar data mudah untuk dipahami mengenai hasil penelitian penulis, kemudian langkah terakhir ialah dengan memverivikasi data atau menarik kesimpulan dari hasil penelitian penulis.

Dalam teknik keabsahan data, penulis melakukan uji kredibilitas data dengan pengamatan, peningkatan ketekunan, triangulasi atas hasil analisis data penelitian yang penulis lakukan

\section{TEMUAN PENELITIAN DAN PEMBAHASAN}

\section{Pelaksanaan Underwriting Pada Asuransi Takaful Keluarga Cabang Bengkulu}

Berdasarkan hasil wawancara penulis dengan pihak Asuransi Takaful Keluarga Bengkulu, bapak Arif mengatakan: "dalam proses pengajuan polis asuransi, calon tertanggung atau calon nasabah dengan petugas asuransi akan membuat persetujuan terhadap akad mengenai sistem asuransi yang akan diterima, dan selain itu calon tertanggung atau calon nasabah harus lolos seleksi underwriting terlebih dahulu. Hal ini dilakukan untuk meminimalisir resiko yang akan terjadi". (Arif Sudibyo, Pimpinan Asuransi takaful keluarga Bengkulu, wawanara 27 Desember 2018).

Dalam proses underwriting atau dalam proses memastikan calon tertanggung layak dijamin, maka calon tersebut harus siap melakukan serangkain seleksi resiko. Adapun langkah-langkah proses underwriting sebagai berikut :

1. Field underwriting

2. Verifikasi berkas dan data aplikasi

3. Mengumpulkan informasi tambahan

4. Keputusan underwriting

Setelah melakukan serangkaian proses diatas maka seorang underwriter memiliki hak untuk membatalkan atau menentukan polis asuransi yang akan digunakan. Dalam menetapkan keputusan underwriting perusahaan Asuransi Takaful Keluarga menetapkan empat keputusan yaitu:

1. Asuransi diterima standar

2. Asuransi diterima subtandar

3. Asuransi ditunda

4. Asuransi ditolak 
Faktor-Faktor yang Menjadi

Pertimbangan Underwriter dalam Menyeleksi Resiko

Ada 2 Faktor yang menjadi pertimbangan underwriter dalam menyeleksi resiko. Pertama faktor medical kemudian yang kedua faktor non medical. Faktor medical meliputi (Arif Sudibyo, Pimpinan Asuransi takaful keluarga Bengkulu, wawanara 27 Desember 2018). :

1. Berat badan.

2. Kondisi fisik selain berat badan.

3. Riwayat kesehatan keluarga.

4. Merokok.

Adapun yang menjadi faktor non medical meliputi :

1. Pekerjaan

2. Avokasi dan kesenangan

3. Aviasi

4. Moral hazard

5. Tempat tinggal

6. Keadaan ekonomi

7. Suku bangsa

8. Jenis kelamin.

9. Insurable interest.

10. Anti seleksi keuangan

Tingkat risiko yang paling umum diterapkan oleh perusahaan asuransi jiwa adalah: Pertama, standard. Yang termasuk dalam tingkat risiko standard adalah mereka yang mempunyai tingkat risiko kematian rata-rata. Sehingga membayar tarif premi asuransi dengan tarif standar. Hal tersebut dapat dilihat dari usia calon pemgenag polis yang di bawah 55 tahun dan tidak ada mempunyai catatan penyakit yang membahayakan, kemudian mempunyai pemasukan yang cukup untuk memenuhi kewajiban pembayaran premi asuransi.

Kedua, substandard. Yang termasuk dalam risiko substandard adalah orang-orang yang mengalami penurunan kualitas medical dan nonmedical, sehingga tingkat risiko kematiannya lebih tinggi daripada rata-rata. Tingkat risiko ini dikenakan tarif premi lebih tinggi dari rata-rata, tergantung tingkat risiko yang dimiliki. Hal tersebut dapat dilihat jika usia calon pemegang polis diatas 55 tahun atau usia yang normal tetapi mempunyai riwayat penyakit, hal demikian dapat diukur dengan hasil medical check up-nya.

Ketiga, preffered (prioritas). yang termasuk kategori tingkat risiko ini adalah orang-orang yang mempunyai risiko kematian di bawah rata-rata. Ciri khas orang-orang yang termasuk kategori tingkat risiko ini adalah orang-orang yang mempunyai kondisi fisik sangat baik, riwayat kesehatan pribadi dan keluarga baik, dan tidak merokok. Tingkat risiko preferred dikenakan tarif premi dibawah ratarata.

Keempat, nonsmoker (bukan perokok). yang termasuk dalam 
kategori ini adalah mereka yang tidak menghisap rokok atau bagi yang merokok jangka waktu dikategorisasikan tingkat risiko ini adalah 12 bulan. Maksudnya dalam kurun waktu 12 bulan telah meninggalkan kebiasaan merokok.

Kelima, uninsurable (tidak dapat diasuransikan). Yang termasuk ke dalam tingkat risiko uninsurable adalah orang-orang yang mempunyai risiko kematian tinggi, sehingga menyebabkan perusahaan tidak bersedia menanggung mereka. Biasanya underwriter akan menolak permohonan calon peserta yang masuk dalam kategori ini. Orang yang secara usia sudah terlalu tua, mempunyai riwayat penyakit kronis dan tidak mampu memenuhi premi tambahan. (Linda Hariyanti, Staff Asuransi Takaful Keluarga cabang Bengkulu, wawancara, 28 Desember 2018).

Ada cara-cara dalam menetapkan suatu kondisi underwriting yaitu: Pertama, ekstra premi. Jika suatu risiko adalah dari jenis risiko yang menaik, maka pengenaan tambahan level ekstra adalah metode yang tepat. Perusahaan asuransi akan menerima risiko ekstra sebelum risiko tersebut semakin berat, karena sebagian risiko tersebut dikaitkan dengan kesehatan.

Kedua, debt on the sum assured. Sebagai pengganti ekstra premi, pemegang polis dapat memilih alternatif yaitu membayar premi standar sesuai table dengan menerima penutupan asuransi jiwa lebih rendah dari uang pertanggungan yang telah ditetapkan.:

1. Masa observasi (liening condition). Calon peserta yang dikenakan ekstra mortalita yang tinggi dapat diganti dengan alternatif manfaat meninggal pada awal tahun yang kecil.

2. Perubahan kontrak (alteration of contract).

3. Perubahan kontrak/jangka waktu perjanjian.

4. Pengecualian (exclusion).

Daripada underwriting menolak suatu permintaan asuransi, karena adanya suatu medical impairment.

5. Ditunda atau ditolak (postpone or decline). (Linda Hariyanti, Staff Asuransi Takaful Keluarga cabang Bengkulu, wawancara, 28 Desember 2018).

\section{Pandangan Maqashid Syariah} Terhadap Pelaksanaan Underwriting Pada Asuransi Takaful Keluarga Cabang Bengkulu

Seleksi resiko yang dilakukan perusahaan asuransi tersebut menghilangkan prinsip dari tolongmenolong. Pada sisi lain, dalam underwrting yang dilakukan Asuransi Takaful Keluarga Cabang Bengkulu mempunyai tujuan untuk menjaga 
kemaslahatan,

khususnya

kemaslahatan bagi jiwa dan harta peserta asuransi.

Perlindungan

demikian

dianggap penting, mengingat didalam hukum Islam dikenal dengan maqashid asy-syariah, yang berarti tujuan-tujuan ditetapkannya hukum dalam Islam. Tujuan dari ditetapkannya hukum Islam dalam masyarakat adalah untuk melindungi kehidupan manusia agar terjaga eksistensinya. Tujuan dari hukum Islam adalah maslahah (kemaslahatan). Ada lima aspek yang dilindungi oleh syara' yang dikenal dengan al-kuliyyah al-khams, meliputi agama (din), jiwa (nafs), akal (aql), keturunan (nasl), dan harta (maal).

Untuk itu penulis menitik beratkan perspektif perlindungan jiwa (nafs) dan harta (maal) dalam seleksi resiko di Asuransi Takaful Keluarga Cabang Bengkulu.

1. Underwriting dalam kemaslahatan jiwa (Hifz al-Nafs)

Jiwa sebagai salah satu aspek ditetapkkannya hukum Islam, dan menjadi aspek yang harus dilindungi. Atas dasar itu, dalam aspek salbiyah Islam melarang pembunuhan dan pelakunya diancam hukuman qishas (pembalasan setimpal). Hal ini di atur dalam QS Al-Baqarah ayat 178179

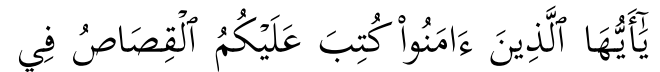

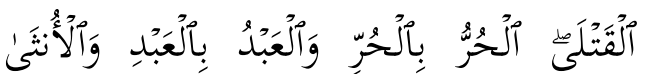

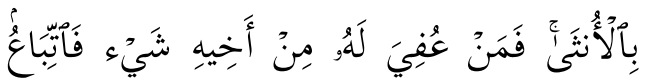

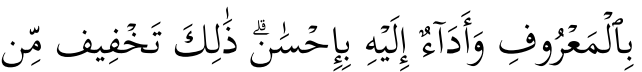

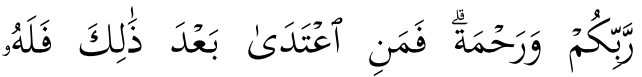

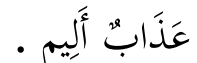

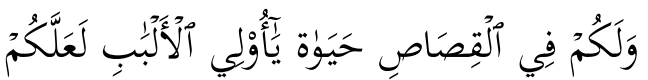
تَتَّقُونَ

"Hai orang-orang yang beriman, diwajibkan atas kamu qishaash berkenaan dengan orang-orang yang dibunuh; orang merdeka dengan orang merdeka, hamba dengan hamba, dan wanita dengan wanita. Maka barangsiapa yang mendapat suatu pemaafan dari saudaranya, hendaklah (yang memaafkan) mengikuti dengan cara yang baik, dan hendaklah (yang diberi maaf) membayar (diat) kepada yang memberi maaf dengan cara yang baik (pula). Yang demikian itu adalah suatu keringanan dari Tuhan kamu dan suatu rahmat. Barangsiapa yang melampaui batas sesudah itu, maka baginya siksa yang sangat pedih. (178)Dan dalam qishaash itu ada (jaminan kelangsungan) hidup bagimu, hai orang-orang yang berakal, supaya kamu bertakwa (179)."

Adapun pelarangan dalam Islam dalam membunuh anak-anak 
karena takut miskin, maupun pembunuhan yang tidak dibenarkan oleh syara'. Sementara

itu, al-Qur'an menjelaskan mengenai penghormatan terhadap jiwa seseorang. Allah SWT berfirman dalam QS an-Nisa' ayat 92-93

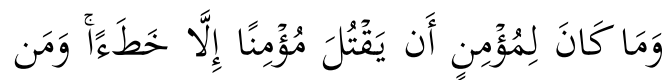

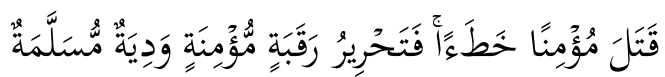

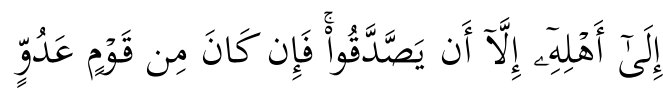

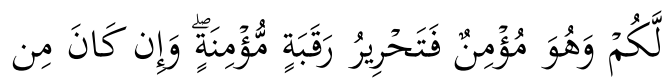

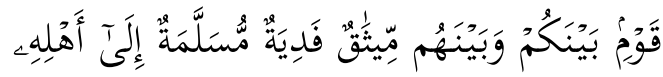

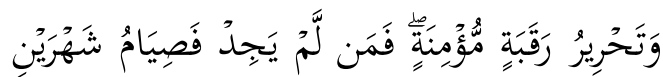

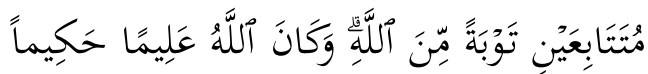

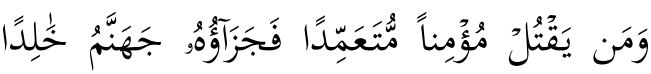

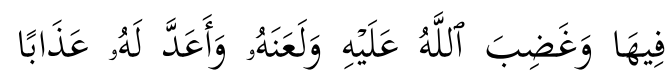

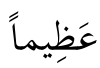

"Dan tidak layak bagi seorang mukmin membunuh seorang mukmin (yang lain), kecuali karena tersalah (tidak sengaja), dan barangsiapa membunuh seorang mukmin karena tersalah (hendaklah) ia memerdekakan seorang hamba sahaya yang beriman serta membayar diat yang diserahkan kepada keluarganya (si terbunuh itu), kecuali jika mereka (keluarga terbunuh) bersedekah. Jika ia (si terbunuh) dari kaum (kafir) yang ada perjanjian (damai) antara mereka dengan kamu, maka (hendaklah si pembunuh) membayar diat yang diserahkan kepada keluarganya (si terbunuh) serta memerdekakan hamba sahaya yang beriman. Barangsiapa yang tidak memperolehnya, maka hendaklah ia (si pembunuh) berpuasa dua bulan berturut-turut untuk penerimaan taubat dari pada Allah. Dan adalah Allah Maha Mengetahui lagi Maha Bijaksana.(92). Dan barangsiapa yang membunuh seorang mukmin dengan sengaja maka balasannya ialah Jahannam, kekal ia di dalamnya dan Allah murka kepadanya, dan mengutukinya serta menyediakan azab yang besar baginya (93)."

Ayat diatas menjelaskan tentang larangan membunuh terhadap muslim lainnya dan kewajiban hukum bagi si pembunuh jika pembunuhan itu benar-benar terjadi. Perwujudan kemaslahatan jiwa dari aspek positif (ijabiyah) diwujudkan melalui perkawinan yang bertujuan utnuk melestarikan keturunan. Perlindungan jiwa pada level dharuriyyah dapat dilakukan dengan cara memenuhi kebutuhan pokok, seperti makanan untuk mempertahankan hidup. Perwujudan kemaslahatan jiwa dari aspek negatif (salbiyah). Cara kerjanya melalui penolakan 
maupun pencegahan dari hal-hal yang akan merusak jiwa dan atau raga (Kuat Ismanto, 2016 : 140).

Kepentingan yang dapat diasuransikan pada perlindungan jiwa adalah keberlangsungan jiwa ataupun anggota badan yang dimiliki seseorang, dimana jiwa terjadi sesuatu akan menimbulkan kerugian finansial.

Adanya underwriting mengenai perlindungan jiwa yaitu, dengan seleksi resiko yang dilakukan oleh pihak undewriter membuat anggota lainnya menjaga kesehatannya dan menjaga kondisi ekonominya untuk memikirkan kemasa yang akan datang demi anak keturunannya. Dalam hal ini untuk mencapai kemaslahatan tersebut, maka calon pemegang polis pun mencengah keburukan-keburukan yang kan timbul. Hal tersebut sesuai dengan kaidah fiqih

$$
\text { درء المفاسد مقدم على جلب المصالح }
$$

"Menolak kerusakan (mafsadat) lebih didahulukan daripada menarik kemaslahatan)." (Faturahman, 2015 : 111)

Dalam underwriting juga melindungi pemegang polis yang telah terdaftar agar tidak ikut menanggung beban yang lebih berat antara sesama pemegang polis. Tujuan hukum dari underwriting tersebut agar resikoresiko yang relatif homogen dari kelompok peserta tertentu agar dapat memberikan skema pembagian resiko yang proposional, adil, dan terjangkau terhadap sesama pemegang polis. Karena pada hakikatnya dalam asuransi jiwa syariah peserta asuransi saling menanggung dan perusahaan hanya sebatas pemegang dan pengelola dana santunan tersebut.

2. Underwriting dalam kemaslahatan harta (Hifz al-Maal)

Harta merupakan salah satu aspek maqasid asy-syariah yang harus dilindungi oleh syariah. Meskipun pada dasarnya harta milik Allah tetapi manusia memiliki hak kepemilikan dan kewajiban mengelolanya dengan baik. Aturan main dalam bidang ekonomi dalam Islam diatur dalam fiqih muamalat. Islam membolehkan seluruh transaksi bisnis kecuali ada dalil yang melarangnya. Oleh karena itu bentuk transaksi ekonomi seperti jual beli, rahn, mudharabah, musyarakah, dan lain-lainnya menjadi halal. Kegiatan tersebut termasuk hal positif (ijabiyyah).

Adapun aspek negatif (salbiyah) Islam melarang semua transaksi ekonomi yang mengandung unsur riba, maisir, gharar, zhalim taqrir 
(spekulasi tinggi), tadlis (penipuan). Allah SWT berfirman dalam QS alBaqarah ayat 275 :

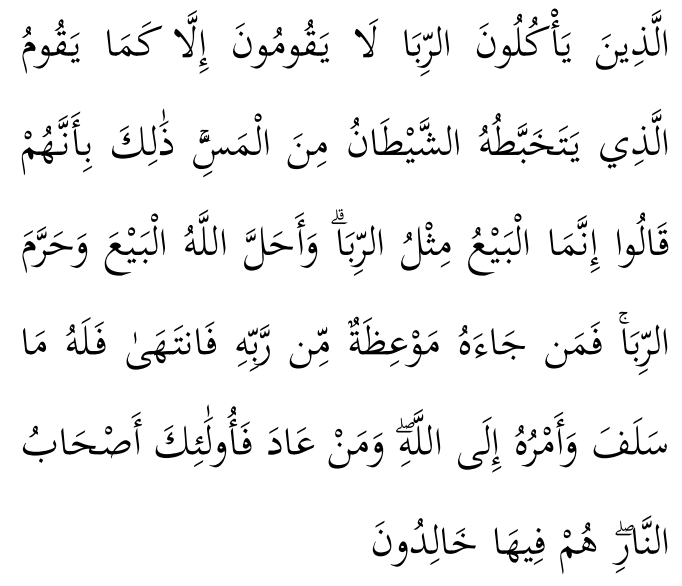

Artinya : "Orang-orang yang makan (mengambil) riba tidak dapat berdiri melainkan seperti berdirinya orang yang kemasukan syaitan lantaran (tekanan) penyakit gila. Keadaan mereka yang demikian itu, adalah disebabkan mereka berkata (berpendapat), sesungguhnya jual beli itu sama dengan riba, padahal Allah telah menghalalkan jual beli dan mengharamkan riba. Orang-orang yang telah sampai kepadanya larangan dari Tuhannya, lalu terus berhenti (dari mengambil riba), maka baginya apa yang telah diambilnya dahulu (sebelum datang larangan); dan urusannya (terserah) kepada Allah. Orang yang kembali (mengambil riba), maka orang itu adalah penghunipenghuni neraka; mereka kekal di dalamnya."

Ayat diatas menjelaskan tentang larangan riba, Allah memberikan solusi transakski yang benar bahwa dengan cara jual beli di halalkan dan Allah mengharaman riba.

Perlindungan asuransi pada kemaslahatan harta terletak pada aspek negatif (salbiyah). Umumnya terdapat pada asuransi umum seperti penanggulangan resiko atas kehilangan, penanggulangan resiko atas kerugian, penanggulangan resiko atas kehilangan manfaat yang timbul akibat pristiwa yang tidak diinginkan.

Adapun dalam aspek positif (ijabiyyah) diwujudkan dalam pengelolaan dana premi seluruh pemegang polis oleh perusahaan asuransi takaful keluarga, yang kemudian ditasaruf-kan untuk mencapat profit yang menguntungkan baik bagi pihak pemegang polis dan pihak perusahaan atau pengelola dana. Pengelolaan tersebut digunakan dalam berbagai instrument seperti pasar uang syariah, reksadana syariah, saham sayariah, sukuk, deposito mudharabah, dan lain lain. Untuk itu, dalam asuransi takaful keluarga ada program Fulnadi yang alokasi pembagian untuk dana tabbaru' 20\% dari jumlah premi dan untuk dana tijarah $80 \%$ dari jumlah premi (Arif Sudibyo, Pimpinan Asuransi 
takaful keluarga Bengkulu, wawanara 27 Desember 2018).

Artinya, dominan dana premi pemegang polis digunakan untuk hal produktif demi menjaga kemaslahatan harta peserta asuransi. Dalam underwriting juga melindungi pemegang polis untuk menjaga hartanya agar digunakan untuk hal-hal yang mendesak di masa mendatang dan tidak boros dimasa saat ini. Hal tersebut terungkap ketika calon pemegang polis menginginkan santunan yang lebih besar dari yang ditawarkan perusahaan asuransi takaful keluarga dikarenakan jumlah tanggungannya atau jumlah ahli warisnya yang banyak. Maka calon pemegang polis tersebut menambah ekstra premi dari yang ditetapkan oleh perusahaan Asuransi Takaful Keluarga tersebut.

Tujuan hukum dari underwriting tersebut agar resikoresiko yang relatif besar diimbangi dengan dana tabungan dan sumbanagan yang juga besar, agar dapat memberikan skema pembagian resiko yang proposional, adil, dan terjangkau terhadap sesama pemegang polis dan juga memberikan ruang kepada perusahaan untuk mengelola dana premi tersebut ke jalan produktif yang tentunya sesuai dengan prinsip-prinsip Islam.

Perusahaan asuransi jiwa syariah pasti menginginkan terjadinya surplus underwriting, itu berdampak dari sehatnya keuangan perusahaan dan sejahteraan kumpulan dana premi para pemegang polis. Maka dalam hal ini pihak asuransi menjadi selektif dalam memilih resiko, hal itu untuk menjaga dana umat yang terkumpul dalam Asuransi Takaful Kelaurga. Apabila pihak

underwriter tidak selektif dalam menyeleksi resiko, maka akan berdampak susutnya dana tabbaru' pada asuransi tersebut. Hal demikian dapat merugikan para pemegang polis. Maka dalam hal tersbut berlakulah kaidah fiqih mengenai.

الِذَا تَعَارَضَ مَفسَدَتَانِ ر وعِعَ اَ عظَمهمَا ضَر را بِا رتِكَابِ اَيَفِّهمَا “Apabila dua buah kemudharatan saling berlawanan maka haruslah dipelihara yang lebih berat mudharatnya dengan melaksanakan yang lebih ringan dari padanya" (Faturahman, 2015 : 112)

Ketika pihak underwriter menolak calon pemegang polis dengan alasan kesehatan yang 
tidak memenuhi syarat atau hal lainnya, pada hakikatnya pihak underwriter tersebut sedang melindungi dana tabbaru' dari kesusutan. Hal tersebut membuat pihak asuransi memilih kemudharatan yang besar daripada kemudharatan yang kecil. Kemudharatan yang besar disini yaitu menjaga dana tabbaru' agar tidak susut artinya menjaga dana umat yang banyak. Kemudharatan yang keciil disini ialah menolak calon pemegang polis karena ditakutkan akan berakibat hal yang tidak diinginkan mengenai surplus underwriting dari dana tabbaru' tersebut.

\section{PENUTUP}

Berdasarkan analisa yang telah penulis paparkan, maka dapat di tarik kesimpulan sebagai berikut :

Dalam pelaksanaan underwriting atau penyeleksian resiko pada Asuransi Takaful Keluarga Cabang Bengkulu pada umumnya telah melaksanakan sesuai dengan peraturan dan ketetapan yang ada pada perusahaan asuransi. Adapun langkah-langkah proses underwriting dimulai dari field underwriting, verifikasi berkas dan data aplikasi, mengumpulkan informasi tambahan, menilai resiko, dan keputusan underwriting. Kemudian keputusan underwriting perusahaan Asuransi Takaful Keluarga Cabang Bengkulu menetapkan empat keputusan yaitu; asuransi diterima standar, asuransi diterima substandar, asuransi ditunda, dan asuransi ditolak.

Adapun faktor yang menjadi pertimbangan underwriter dalam menyeleksi resiko ada dua, pertama faktor medical yang meliputi; berat badan, kondisi fisik selain berat badan, riwayat kesehatan keluarga, merokok, kemudian faktor non-medical, meliputi; pekerjaan, avokasi dan kesenangan, aviasi, Moral hazard, Tempat tinggal, keadaan ekonomi, suku bangsa, jenis kelamin, insurable interest, anti seleksi keuangan.

Pandangan maqashid syariah terhadap underwriting dalam Asuransi Takaful Keluarga Cabang Bengkulu dalam pelindungan jiwa (Hifz al-Nafs) underwriting melindungi pemegang polis yang telah terdaftar agar tidak ikut menanggung beban yang lebih berat antara sesama pemegang polis. Tujuan hukum dari underwriting tersebut agar resiko-resiko yang relatif homogen dari kelompok peserta tertentu agar dapat memberikan skema pembagian resiko yang proposional, adil, dan terjangkau terhadap sesama pemegang polis. Kemudian dalam perlindungan harta (Hifz al-Maal) tujuan hukum dari underwriting tersebut agar resiko- 
resiko yang relatif besar diimbangi dengan dana tabungan dan sumbangan yang juga besar, agar dapat memberikan skema pembagian resiko yang proposional, adil, dan terjangkau terhadap sesama pemegang polis dan juga memberikan ruang kepada perusahaan untuk mengelola dana premi tersebut ke jalan produktif yang tentunya sesuai dengan prinsip-prinsip Islam.

\section{Saran}

Jurnal ini bukan akhir dari sebuah penelitian ilmiah terhadap tema yang sedang diteliti, karena bisa jadi merupakan titik awal terhadap beberapa persoalan yang juga dianggap strategis untuk dikaji lebih komprehensif bagi peneliti lainnya. Sehingga penulis berharap jurnal ini dapat lebih disempurnakan lagi melalui penelitian-penelitian yang akan datang.

\section{KEPUSTAKAAN ACUAN}

Al-Qur'an Karim

Kun A R Rezky, (2015), Asuransi syariah, Yogyakarta: Parama Publising

Sudarsono, Heri. (2004), Bank dan Lembaga Keuangan Syari'ah, Yogyakarta: UII Pres

Hastuti, Permata. (2016), Asuransi konvensional, syariah dan BPJS, Yogyakarta: parama publishing
Amrin, Abdullah. (2006), Asuransi: Keberadaan dan Kelebihannya di Tengah Asuransi Konvensional, Jakarta: Elex Media Komputindo

Peraturan Otoritas Jasa Keuangan NOMOR 69 /POJK.05/2016 Tentang Penyelenggaraan Usaha Perusahaan Asuransi, Perusahaan Asuransi Syariah, Perusahaan Reasuransi, Dan Perusahaan Reasuransi Syariah Undang-Undang No 40 Tahun 2014 tentang perasuransian

Dewi, Gamala. (2004), Aspek-Aspek Hukum Dalam Perbankan $\mathcal{E}$ Perasuransian Syari'ah di Indonesia, Jakarta : Kencana

Hajar. Ibnu. al-Asqalani, penerjemah Khalifaturrahman dan Haer Haeruddin, (2013), BULUGHUL MARAM \& Dalil-dalil hukum, Jakarta : Gema Insani

Software Kitab 9 Imam hadist

Irham, Fahmi. (2014), Bank dan lembaga keuangan lainnya, Bandung : Alfhabeta Iqbal, M. (2005), Asuransi Umum Syari'ah dalam Praktik (Upaya menghilangkan gharar, Maisir, dan Riba), Jakarta : Gema Insani

Syarifuddin, Amir. (2008), Ushul Figh jilid 1, Jakarta : Kencana

Syarifuddin, Amir. (2008), Ushul Fiqh jilid 2, Jakarta : Kencana 
Syathibi, Abu Ishaq Ibrahim ibn Musa, Ismanto, Kuat, (2016), Asuransi n.d. Al-Muwafaqoh fi Ushul alAhkam, Kairo: Mustafa Muhammad

Perspektif Maqasid Asy-Syari'ah, Yogyakarta : Pusaka Pelajar.

Khallaf, Abdul Wahab, (1956), Ilmu Ushul Fiqh, Kairo: Dar al- Qalam.

Sugiyono, (2013), Metode Penelitian Kuantitatif, Kualitatif, dan RED, Bandung : Alfabeta.

Azhari, Faturahman, (2015), Qawaid Fiqhiyah Muamalah, Banjarmasin : Lembaga Pemberdayaan Kualitas Umat (LPKU) Banjarmasin 